\title{
ANALYSIS OF THE PROCESS RELATED TO THE OPERATIONS MANAGEMENT OF THE RAIL TRACTION VEHICLES IN JSC "SERBIAN RAILWAYS"
}

\author{
Vojislav VUKADINOVIĆ ${ }^{1}$, Cariša BEŠIÍ ${ }^{2}$, Snežana BEŠIĆ ${ }^{3}$ \\ ${ }^{1}$ Srbija Voz a.d., 11000 Belgrade, Nemanjina 6, Republic of Serbia \\ ${ }^{2}$ University of Kragujevac, Faculty of Technical Sciences in Čačak, 32000 Čačak, Svetog Save 65, \\ Republic of Serbia \\ E-mail: carisa.besic@sbb.rs \\ ${ }^{3}$ Higher Education Railway School of Professional Studies, 11000 Beograd, Zdravka Čelara 14, \\ Republic of Serbia
}

Paper received: 14.11.2016.; Paper accepted: 28.11.2016.

\begin{abstract}
In the study, issues related to the operations management in railway were elaborated, with special emphasis on the operations management of rail vehicles and main parameters in its activities and in the railway functioning. The analysis of the current status, operation and functioning of the Serbian Railways was also provided, with a special focus on the study of the technical condition regarding exploitation, reliability, and availability of traction vehicles operation which is always actual and particularly important for ensuring the regular and safe functioning of train traffic in all railways in the world as well as in the railway of Serbia. The issue related to the exploitation reliability and availability regarding traction vehicles operation is also being analyzed which is reflected in development of the concept and creation of the methodology for assessment of the technical condition and indicators for determining the level of exploitation reliability, availability of the traction vehicle operation as well as functioning of train traffic and the models related to the operations management of rail traction vehicles.
\end{abstract}

Keywords: Operations management, Railway, Traction vehicles.

\section{INTRODUCTION}

The main purpose of management is to make a specific set of business decisions in order to achieve the goals related to business organization. According to some views (Đorđević and Ćoćkalo, 2012), the management process involves a continuous process which initiates and directs the business activity aiming to realize the business goals.

In general (Bogetić, 2015) management processes in transportation companies include planning, organization, managing and controlling. The purpose of the management process is to achieve the desired level of activities in order to enable the most successful traffic operation and the largest volume of the passenger and freight transport. The management process is based on the continuous study and restructuring of railways companies in constant search for the best solutions in terms of the rational business and economic activities.

In railway, the management process is performed by five functions: organization, management (managing), personnel management and control of the activities of the organizational units as well as the use of all available resources of the railway companies in order to achieve the particular goals.

Management of the whole process of railway transport is achieved through special part of the management system in railway system known as system of operations management in railway.

Operations management involves directing and organizing the set of the activities which defines the realization of the operational goals and 
economic efficiency within the shortest possible period (Sajfert et al., 2006).

The system of the operations management in railway also contains operational planning as an integral part of the unique unit, which is carried out within the following functional units in connection with the transportation process:

- management of coach operation,

- management of traction vehicle operation (train traction),

- management of operation (movement) of trains,

- management of rolling stock maintenance (traction vehicles and coaches), rails and rail facilities, SS and TK devices in SPEV, and

- process of transportation in railway.

The system of operations management of railway transport in JSC Serbian Railways can be represented as a pyramid with three hierarchical level of management:

1. Operations management of the basic activities at the level of railway undertakings (strategic management)

2. Operations management at the level of pjunits in basic activities in railway (tactical management)

3. Operations management at the level of basic and executive units in the basic activities of the railway (executive level - direct management of work processes)

Operation management of rail traction vehicles represents one subsystem with basic executive function in the system of operations management in the railway.

\section{ANALYSIS OF THE TRACTION ROLLING STOCK CONDITION ON THE NETWORK OF SERBIAN RAILWAYS}

The research of the treated issues - improvement of the operations management process related to the rail traction vehicles was carried out on the territory of Serbian Railways, which in 2012 encompassed rail network, with a total length of $3808,7 \mathrm{~km}$, of which $1278 \mathrm{~km}$ were electrified, that makes about $33,6 \%$ of total rail length for the electric traction system application and it had available, nominally, a total inventory traction fleet consisted of 436,5 traction vehicles of all types and series, including 143 electric locomotives, 193 diesel locomotive and 3 steam locomotives from the composition of the tourist museum train
„Romantika“ (Report on..., 2013; Operational..., 2013), as well as 38,5 sets of electric motor units series 412 and 59 sets of diesel motor units of a different series. Due to the large number of different series, of which, in 2012, on Serbian Railways, there were 19 different series, of which 14 series of locomotives and 5 series of multiple units, it was necessary to perform a research using a particular sample of traction vehicles.

The aforementioned research was performed using the sample with a size of 208 locomotives of leading series which covers about $61.3 \%$ of the total locomotive inventory fleet, and sample consisted of 63.5 sets of electric motor and diesel motor units, which covers about $65 \%$ of the total traction fleet of all motor unit sets, of which in the sample composition entered all 38.5 electric motor units and 25 diesel motor units series 812 . Observed sample includes all 143 electric locomotives, i.e. $100 \%$ of the existing three series (441, 444 and 461) and 65 diesel locomotives series 661 which represents approximately $33.7 \%$ of the total number of 193 diesel locomotives of all series within 10 existing series and types of diesel locomotives.

In the process related to the research of the aforementioned issue, primarily, it was necessary to ascertain the status and condition of the traction vehicles within the observed sample in terms of their number status of the total inventory fleet of traction vehicles and status of the active inventory fleet of traction vehicles, fleet of traction vehicles in the process of repair and, finally the size of the total working fleet of traction vehicles and their allocation by territorial units - train traction units on the network of Serbian Railways. Exploring the data from available official documentation (Report on..., 2013; Operational..., 2013) defined status conditions related to the observed traction fleets were ascertained. It was ascertained that in the sample, on the day of observation (31.01.2012), in its total inventory fleet, there were 271,5 traction vehicles, active inventory fleet of traction vehicles included 235 traction vehicles of the observed series, of which 109 traction vehicles (about $46,4 \%$ ) were in fleet that was in operation and 126 traction vehicles (about 53,6\%) were in fleet that was not in operation, on various repairs or awaiting them.

The maximum total number of defects in the observed period was ascertained when it comes to the locomotive series 461 , and the lowest number 
when it comes to the locomotive series 444 . The number of defects of motor units is $18 \%$ of the total number of defects of all traction vehicles. Within this research it was very important to establish an overview of parallel comparison of the observed locomotives in terms of their number status of the total inventory fleet and the fleet that was in operation as well as average number of defects per one locomotive in operation.

The total number of defects and average number of defects per locomotive which is in operation has the following character of movement:

- On the locomotive series 444 there is a general trend of increasing,

- On the locomotive series 441 the total number of defects has a trend of increasing while the average number of defects per locomotive which is in operation, has oscillating movement (increase and decrease) in certain years within the observed period,

- On the locomotive series 461 the total number of defects has a general trend of decreasing, and the average number of defects per locomotive which is in operation has oscillating movement (increase and decrease, increase) in certain years within the observed period

- On the locomotive series 661 the total number of defects and average number of defects of locomotives which is in operation has oscillating movement (decrease and increase) in certain years within the observed period and finally,

- For all locomotives of the observed series the total number of defects and average number of defects per locomotive which is in operation has oscillating movement (increase, decrease, increase) in certain years within the observed period (Vukadinović, 2016).

Based on the conducted research of data from the report from JSC Serbian Railways (Report on..., 2013; Operational..., 2013), it can be ascertained that age structure of the locomotives from the sample of the observed series in Serbian Railways is very unfavorable, given that, considering the total number of locomotives of the active inventory fleet, only 38 locomotives (about 20.2\%) are under ten years of age, and that only six locomotives (about 3.2\%) are between 20-29 years of age, and that 70 locomotives (about 37.2\%) are between 30 and 39 years of age, which recommended cycle of exploitation expires or has already expired, and on
74 locomotives (about 39.5\%) the recommended exploitation life expired a long time ago.

The maximum number of locomotives (144 or $76,5 \%$ ) are between 30 and 55 years of age and only 44 locomotives or $23 ., 5 \%$ are 30 years old. Seventy-four locomotives or $39,6 \%$ of all locomotives the recommended exploitation life expired after completed 40 years of age. According to the data from officials reports (Report on..., 2013; Operational..., 2013) the average age of electric motor units series 412/416 in 2011, was 27.5 year which implies that recommended exploitation life is expiring. But, on diesel motor units series 812 (railcars) the average age was 50,8 which implies that average exploitation life, according to the UIC, expired already in double duration which in any case affects their unsatisfactory technical condition and high percentage of their irregularity (immobilization).

The most influential samples for occurrence of failures, connected together, for all electric locomotives with participation of $22.8 \%$, are defects in connection with the conductors, relays, ep valves, switches and disconnectors. In the second place when it comes to the importance of the influence on occurrence of failures on the locomotives, with participation of $15 \%$, the most dominant are elements of the main circuit. In the third place of importance, for defects occurrence on locomotives, with participation of $11,8 \%$ are the influences of the auxiliary drive devices on the locomotives. In general, the samples of the first, second and third range of importance involve about a half $(49,5 \%)$ of the total number of all defects on locomotives. It is important to mention that the causes related to the $18.34 \%$ of all defects on locomotives were not ascertained.

\section{EVALUATION OF THE CONDITION OF TRACTION FLEET IN THE COMPANY SERBIAN RAILWAYS}

Serbian Railways JSC, with its 18.000 employees and monopoly position in passenger and freight railway transport, is not able to ensure sufficient funds, with revenues of transport, in order to cover costs of regular infrastructure and rolling stock maintenance, to invest in overhaul and modernization of rails and rolling stock as well as salaries to the employees, therefore, the company receives missing funds in form of subsidies from the budget of the Serbian Government in annual amount of 14 billion dinars, that are insufficient. 
It can be ascertained that quality of the service related to the railway transport is not satisfactory. The basic indicators of the quality related to the functioning of train traffic are the following:

- Number of extraordinary events (accidents and incidents) that occurred within the observed period and their consequences (dead and injured persons etc.), as key indicators of train transport safety;

- Delays of trains (total delays and delays per train);

- Delays of trains per 100 train kilometer and

- Commercial speed of train operation in passenger and freight transport.

Aforementioned factors and conditions related to the functioning of train operation had a direct influence on delays and realization of low commercial speeds. According to some views (Bešić and Đorđević, 2014) the key factors of quality in the similar organizations are resources, organizational structure, relationship with customers and attitude of management towards improvement of the business quality. On the other hand, transport companies have to offer high value transportation services in the market and such companies should focus on the quality of the service and it is necessary that they constantly innovate and improve employee productivity, (Vešović, 2003).

Business efficiency and quality of the service are directly related. When we talk about concrete aspects that affect the performance of the modern organization, a particular emphasis is placed on the quality, productivity and innovations, (ĐervidaLekanić et al., 2016). The quality and productivity are related to each other and the employees create the quality of the service organization.

The quality of the passenger service is not satisfactory in the Serbian railways, though delays of passenger trains show a decreasing tendency. The commercial speed of trains is not satisfactory and shows a decreasing tendency during the observed period. The quality related to the functioning of freight transport is not satisfactory, and commercial speed of freight trains is at low level. The level of train traffic safety is not satisfactory in terms of the number of emergencies, casualties and traffic interruption duration, cause the aforementioned indicators have a tendency of increasing, which had a direct impact on the regularity (delays) in train traffic and their proper functioning.

By the Serbian Government Program (Law on Railways, 2013; Program..., 2014), Serbian Railways JSC, in the middle of the year 2015, entered in the process of completion of the commenced restructuring process based on which the company was transformed into three independent technical-technological, functional and organizational units:

1. „Infrastructure of Serbian Railways JSC, as a company for maintenance of railway lines, stations and their equipment, signaling-safety and telecommunication facilities, as well as fixed installations of electric traction on the railway network of Serbia,

2. „Srbija Voz“ JSC, as a railway company for passenger transport i.e. passenger service on the railway network of Serbia and

3. „Srbija Kargo“ JSC as a railway company for freight transport, i.e. freight transport on the railway network of Serbia.

Investments for modernization, overhaul and new railway stock are provided from the loan of EBRD and EUROFIMA as well as commercial banks under relatively favorable financial conditions. But, conditions set by creditors are not favorable for domestic overhaul companies failing to comply with standards and meet the tender requirements, both, in financial terms (provision of bank guarantees) and in the scope and quality of executed works that are evaluated within tenders funded by international financing institutions and commercial banks. In order to maintain the production of domestic overhaul companies, and, among others, technical and scientific basis of the country when it comes to the strategy, the Government of the Republic of Serbia, ensured, using new funding models, the funds for overhaul of the certain number of traction vehicles, passenger and freight cars which shall be performed by domestic overhaul companies. But, in a time of economic crisis and new social economic situation after privatizations carried out over past ten years, when a large number of former economic giants and accompanying cooperators disappeared from economic scene, given that they were permanent customers and taking into account their needs for the transport of the large quantity of goods, the flows of goods, needs of small and medium-sized enterprises, and focus on roads building and small volume of production, depopulation and change of demographic pictures 
of the entire regions in the country, gave priority to passenger and freight transport by road.

In 2012 Serbian Railways carried 16,53 million of passengers and about 9.625 million tons of goods and all indicators are $25-30 \%$ worse compared to 2011. In the previous period that lasts longer than two decades, railway activity in Serbia is performed in poor economic conditions, wars and sanctions, which had also influence on conditions related to the functioning, exploitation, maintenance and availability of all infrastructure capacities, rolling stock, as well as availability of traction vehicles of all series, and on overall business of Serbian Railways.

Unsatisfactory technical condition of the existing traction vehicles in Serbian Railways is characterized by a large number of defect and high percentage of the total immobilization of the observed traction vehicles that within the observed period ranged from $32 \%$ to $65 \%$, which had an effect on very low level of their operation availability, therefore, their coefficient of operation availability ranged from 0.41 to 0.90 during the observed period of five years, when it comes to the observed series of traction vehicles. Lack of funds for regular investment maintenance of traction vehicles is overcome by certain measures such as extension of criteria related to the run kilometers for additional $100.000 \mathrm{~km}$, and in this regard, by decision of the Board of Directors of Serbian Railways JSC, a commission for monitoring the operation of the certain number of traction vehicles was established, but this measure does not provide permanent and systematic solution, it only represents an attempt to exploit maximally the resources of old and inadequately maintained traction vehicles. The consequences are expected: number of defects is increasing, wheel processing becomes more frequent, the level of immobilization is also increasing, operation availability is reduced and costs for upcoming investment repairs have increased.

In records of (Report on..., 2013; Operational..., 2013) it is estimated that unfavorable conditions, related to the economic situation and business activities of Serbian Railways during the previous period of many years are present now and burdened with many, previously known, economic, organizational, and technical-technological difficulties which are manifested through the following weaknesses:
- Poor economic situation, difficult conditions for economic activities and financial insolvency over many years;

- Insufficient and limited amount of subvention funds that Government of the Republic of Serbia provides within annual functioning of Serbian Railways;

- lack of the funds necessary for maintenance, modernization, infrastructure development and renewal of rolling stock, primarily, traction vehicles and other rolling stock;

- lack of the necessary amount of current assets for regular business activities related to the maintenance of traction units and other rolling stock;

- lack of necessary spare parts for repair of traction vehicles;

- lack of equipment and lack of capacities in locomotive depots and workshops for maintenance of traction vehicles and other rolling stock;

- inadequate division of labor, organizations and insufficient technological discipline in executive units for traction vehicles maintenance and finally

- insufficient number of specialized and professional personnel, in executive units, required for inspection of defects and repair of traction vehicles according to their type and series.

Aforementioned characteristics of the unfavorable economic situation related to the business activity of Serbian Railways had an influence on unfavorable condition of the fleet of traction vehicles, and within it also on unsatisfactory technical condition of a part of the active inventory traction fleet of the observed traction vehicles which are very old.

Of the total of 53 locomotives of the active inventory fleet, the age of 31 diesel electro locomotives series 661 (about 58,5\%) is 51-55 and the age of 7 locomotives (about13.5\%) of this series is 40-50 year therefore, recommended exploitation life of all them expired, and the age of the rest of 15 locomotives of this series (about $28 \%$ ) is between 30 and 39 , because younger generation of the locomotives do not exist. The recommended exploitation life of all diesel motor units series 812 (railcars) expired a long ago because their average age is 50,8 years, and their recommended exploitation life, according to UIC, is 25 years. Of the total of 135 electro locomotives 
of the same series, only 38 locomotives (about $28 \%$ ) are up to 10 years old and this number includes 30 locomotives i.e. $22 \%$ of series 444 and 8 locomotives i.e. $6 \%$ series 461 .

Within the total number of electro locomotives, only 6 locomotives i.e. about $4 \%$ are between 20 to 29 years because younger locomotives do not exist and all have series 441. Age of 55 electro locomotives i.e. $41 \%$ is between 30 and 39 , and there are 23 locomotives series 441 (about 17\%) and 32 locomotives series 461 (about 24\%) and expiration date of exploitation life of all of them is approaching. And finally, the age of all 36 locomotives (i.e. about $27 \%$ of the total number) is between 49 and 45 years, where there are 21 locomotives (i.e. about 16\%) series 441 and 15 locomotives series 461 (i.e. about 11\%) and exploitation life of all of them has already expired.

Given that the exploitation life recommended by UICa (International Railway Union), for the observed locomotives, is 40 years, and that in this respect, the recommended life of exploitation of the larger number of the observed diesel electro locomotives (about 39\%) expired long time ago, and for certain number of locomotives this life of exploitation will expired in one year. But, despite the old age, life cycle of the locomotives still lasts. The average age of electro motor units series 412 is 27,5 and their recommended life cycle, according to UIC is 30 years, which implies that expiration date of their exploitation is approaching.

The causes of unsatisfactory technical conditions of regularity and availability of the observed traction vehicles are multiple but in general:

- wear of particular parts of traction vehicles since they are very old,

- insufficient investment funding in current and investment maintenance of traction vehicles,

- untimely provision and lack of sufficient quantity of spare parts and material for current and investment maintenance of traction vehicles,

- insufficient, or partial execution of annual plans for regular repairs of traction vehicles in the previous period,

- accumulation of defective traction vehicles of the observed series awaiting their turn for repair due to lack of their continuous maintenance,

- non compliance with prescribed deadlines, scope of works and technical norms according to the technical instruction for maintenance of traction units during execution of certain inspections and repairs,

- incomplete and inadequate fault diagnosis in determining the real cause of defect and possible failures in maintenance, i.e. exploitation, and therefore, it should be emphasized that causes of $13,8 \%$ of defects on electro locomotive and $8 \%$ defects on diesel motor locomotives, series 661 were not ascertained, which implies insufficient expertise of personnel who perform that tasks,

- lack of proper technical documentation for maintenance,

- inefficiency of the existing system for maintenance of traction vehicles and their repairs that are too long ,

- incomplete records, data and monitoring information system for collection, transmission and processing of data related to the defects and performed repairs, etc. (Vukadinović, 2016).

\section{GUIDELINES FOR ENHANCEMENT OF OPERATIONS MANAGEMENT OF THE RAILWAY TRACTION VEHICLES IN JSC SERBIAN RAILWAYS}

Due to the above mentioned factors in JSC Serbian Railways, a permanent increase of the immobilization of the analyzed traction vehicles series which currently reaches $65 \%$ and the permanent decline in the number of the operational traction vehicles for operation is present and does not meet the requirements for the current volume of traffic, and even less, for its volume increase in the future.

Due to the aforementioned reasons, the existing traction fleet must be renewed or by purchase of the new traction vehicles or by reconstruction and modernization of the existing rail traction vehicles. Procurement i.e. purchase of the new traction vehicles because of the numerous problems and difficulties in the current economic conditions status, which will be present in the future relatively long period, is not achievable due to the fact that the traction vehicles with the performance of the existing ones are very expensive. As an alternative for the renewal of the electric and diesel traction fleet, remains the overhaul of the existing electric locomotives, series 441, 444 and 461 and the diesel locomotives, series 661 that would comprise their overhaul and appropriate modifications. 
Having in mind the economic possibilities, JSC Serbian Railways had planned earlier to carry out the overhaul of 45 locomotives series 661, as much cheaper and satisfactory, for the period 2003 2005 but the implementation of this task was ceased by JSC Serbian Railways because of persistent economic difficulties in the business activities. (Vukadinovic, 2016).

The proposal of this solution should be activated and it will specify its realization in the coming annual business plans of Railways of Serbia in the period up to 2020. It is estimated that the reconstruction and modernization with certain modifications for the performance of the locomotives in the observed series, their technical life cycle would be extended for another 15 to 20 years.

Starting from the aforementioned performed analyzes and the assessment given for the current situation, problems and influential factors of adverse condition, with the aim of improving the technical accuracy and availability of performance activities of the observed traction vehicles in JSC Serbian Railways, the following measures are proposed to be taken in the forthcoming period:

- it is necessary to make a plan and program of long-term sustainable development of the electric and diesel traction system, in accordance with the future development and the needs of the economy for the railway carriage on JSC Serbian Railways lines,

- it is necessary to make a plan and program of reasonable reconstruction and modification of certain number of existing locomotives, series 441 and 461 ,

- it is necessary to make a plan and program of revitalization of locomotives, series 444 and EMUs, series 412,

- it is necessary to make a plan and program of reconstruction and modifications to certain number of existing diesel-electric locomotives, series 661 in JSC Serbian Railways and agree on the new technical and environmental standards in terms of energy efficiency, and reduce the emissions of harmful substances,

- it is necessary to make a plan for scrapping of those locomotives, series 441, 461 and 661 whose repair is not technically and economically reasonable,

- it is necessary to provide the method for obtaining of necessary financial resources and the dynamics for the reconstruction of locomotives, series 441, 461 and 661 and EMU, series 412 and the procurement of new DMUs (series 711) and EMUs (series 413/417) in the annual business plans of the companies JSC Srbija Voz, JSC Srbija Kargo and JSC Serbian Railways for 2017, 2018, 2019 and 2020 in order to replace the deteriorated rail cars and EMUs, series 412,

- it is necessary to obtain the necessary funding which are really needed for the maintenance of locomotives 441, 444, 461, 661, and EMU, series 412 in the annual business plans of JSC Srbija Voz and JSC Srbija Kargo

- it is necessary to establish promptly the plans, annually, quarterly and monthly for the current investment maintenance of electric and diesel electric traction vehicles and control their complete and strict implementation,

- it is necessary to obtain the necessary financial resources for the optimal amount of procurement and continuous inflow of spare parts required for the proper maintenance of all traction vehicles,

- it is necessary to introduce the additional specialist training of electric mechanical engineer experts for the permanent and effective activities of the Commission composed of competent experts for troubleshooting and diagnosis of the traction vehicle technical correctness condition in the locomotive depots and workshops,

- it is necessary to organize the high quality activities of the control acceptance body that would perform the acceptance of the repaired traction vehicles performed in the railway workshops with repair service unit in the place for electric and diesel railway vehicles maintenance activities,

- it is necessary to take the indispensable organizational and technical measures to perform the prescribed control and technical inspections on all traction vehicles in full, both in scope and content and quality, in accordance with the applicable provisions of the valid regulations,

- it is necessary to improve the existing traction vehicles maintenance and operation information system and the method of keeping records of the total time the traction vehicles spend during the cancellation of operation, due to the waiting for repair because of organizational and logistical arrangements at the time of the actual execution of repair, in order to influence the shortening of complete time of repair and thus 
increased safety and time during their operation. For this purpose, a database and networking of all organizational maintenance and train traction units shall be introduced for longer period within the Serbian Railways organization in order that all mechanical data in electronic form and real time are available and which would allow the traction vehicles monitoring for a longer period, their exploitation for both organizations within the JSC Serbian Railways, as well as, for the needs of interested researchers at universities, institutes and other scientific institutions.

Implementation of the proposed measures would contribute to increasing the number of traction vehicles to complete traction vehicles fleet in order to improve their technical condition, the level of reliability and availability of performance for purposes of exploitation in JSC Serbian Railways in the forthcoming period while increasing the level of safety and neatness and overall efficiency of rail transport.

\section{CONCLUSION}

Current condition of the observed JSC Serbian Railways traction vehicles fleet in technical and exploitation terms is weak and it is estimated to be unsatisfactory for the current traffic needs, noting that, in number, it represents the largest part (about $62.8 \%$ ) of the traction vehicles fleet of all series in JSC Serbian Railways traction system. Electric and diesel traction vehicles for the observed series, in the present JSC Serbian Railways exploitation conditions, form the basis of the electric and diesel traction, and serve for the functioning of traffic and traction on the electrified and non-electrified lines.

Weak and unsatisfactory technical condition of traction vehicles observed series is shown by high number of defects, a high percentage of immobilization with a tendency of its growth and the low level of their exploitation reliability and availability. Availability of the observed traction vehicles is always at low level and has a continuous declining trend observed during the five-year period. The current weak technical condition of the observed traction vehicles is caused mainly by their old age and long exploitation life, irregular and inadequate maintenance with the lack of efficiency of the existing system of maintenance in JSC Serbian Railways.
The existing system of maintenance in JSC Serbian Railways is not effective and is not at the satisfactory level due to lack of investment, incomplete logistics support, insufficient and untimely provision of spare parts for maintenance of traction vehicles, all of which contributed to the generally low level of their low technical accuracy, and high percentage of immobilization, a lot of time spent in repairs, as mentioned above, which ultimately affected the low level of exploitation reliability and availability of activities of the observed towing vehicles.

Based on many years of experience gained from monitoring the behavior of the observed traction in service and maintenance in our railways and other neighboring railways, as well as the current economic situation of JSC Serbian Railways, it is rated as appropriate to take certain actions for these traction vehicles for the revitalization and improvement of the technical conditions.

In order to improve technical condition of the observed traction vehicles of all series it is necessary to improve the efficiency of the existing system of maintenance by introduction of replacement of aggregate system for spare parts and assemblies with the gradual transition from the principle of preventive maintenance to the maintenance according to their diagnosed condition. By taking forward and implementing the proposed measures, the technical condition and the number of traction vehicles in order, and the level of their exploitation reliability and availability in JSC Serbian Railways these activities would be improved.

Given the ongoing reform of JSC Serbian Railways and the transition to the new organizational structure, with the imperative for rationalization of operating costs, the proposed measures, even in these conditions, can be implemented and they can contribute to more efficient business management. Since in the world and Europe the investment in rail transport is increased, in accordance with EU Directives, known for its comparative advantages with economic, environmental, energy and security point of view, it is not only necessary to stress the importance of railways for the development of our country and economy, particularly taking into account the geographical position of Serbia, but it is necessary to urgently resolve the serious problem of the railways at the state level, activate the economic potential and restore the production 
of basic industries in the country, which would allow the increased participation of railway traffic in the transport of goods and passengers compared to the other modes of transport. Transformation and modernization process of our railways will, in optimal conditions, last at least one to two decades, until the traction fleet modernization, reconstruction and electrification of the planned railway lines sections is finished, so the traction vehicle observed series will be the main topic in the rail traction fleet in JSC Serbian Railways and the proposed measures and conclusions, if implemented, in addition to the increased availability of traction vehicles activities, would have their economic justification.

\section{REFERENCES}

. Operational evidence and report on exploitation and activities of traction vehicles in JSC Serbian Railways traction fleet 2008-2012 [in Serbian].. (2013). JSC Serbian Railways, Belgrade.

. Report on Functionality of Service in JSC Serbian Railways 2008-2012 [in Serbian]. (2013). Belgrade: JSC Serbian Railways.
. The Program of Serbian Government [in Serbian]. (2014). Belgrade: Serbian Government.

Bešić, C,\& Đorđević, D. (2014). Management of knowledge [in Serbian]. Čačak: Faculty of technical Sciences.

Bogetić, S. (2015). Management in traffic [in Serbian]. Belgrade: Belgrade Business School.

Đervida-Lekanić, R., Bešić, C., Bešić-Vukašinović, D., \& Bešić, S. (2016). The analysis of public relations role in improving corporate social responsibility. Journal of Engineering Management and Competitiveness (JEMC), 6(1), 54-61.

Đorđević, D., \& Ćoćkalo D. (2010). Basis of marketing [in Serbian]. Zrenjanin: Technical faculty „Mihajlo Pupin“.

Đorđević, D., \& Ćoćkalo, D. (2012). Business planning [in Serbian]. Zrenjanin: Technical faculty „Mihajlo Pupin“.

Law on Railways [in Serbian] (2013).

Sajfert, Z., Đorđević, D., \& Bešić C. (2006). Management lexicon [in Serbian]. Zrenjanin: Technical faculty „Mihajlo Pupin“.

Vešović, V. (2003). Management in traffic [in Serbian]. Belgrade: Fuculty of Traffic.

Vukadinović, V. (2016). Development of operations management of railway traction vehicles [in Serbian]. (Doctoral dissertation). Čačak: Faculty of technical sciences, University of Kragujevac.

\section{ANALIZA PROCESA VEZANIH ZA UPRAVLJANJE OPERACIJAMA NA VUČNIM VUČNIM VOZILIMA U AD "ŽELEZNICE SRBIJE"}

U studiji su razrađene pitanja vezana za operativno upravljanje operativom u železnici, sa posebnim naglaskom na operativno upravljanje šinskim vozilima i osnovnim parametarima aktivnosti u funkcionisanju željeznice. Analiza trenutnog statusa, rada i funkcionisanja Železnica Srbije takođe je obezbeđen, sa posebnim osvrtom na studije tehničkih uslova u pogledu eksploatacije, pouzdanosti i dostupnosti rada vučnih vozila, koja je uvek aktuelna i posebno važna za obezbeđenje pravilnog i bezbednog rada vozova u saobraćaju, u svim železnicama u svetu kao i u Železnicama Srbije. Ključni prikazi se odnose na pouzdanost u eksploataciji i raspoloživost u radu za vučna vozila, koji se odnose na analizu, razvoj koncepta i stvaranje metodologije za procenu tehničkog stanja i indikatora za utvrđivanje nivoa pouzdanosti eksploatacije, dostupnost vuče, upravljanje vozilom, kao i funkcionisanje voznog saobraćaja, i modeli koji se odnose na upravljanje operativom železničkih vučnih vozila.

Ključne reči: operativni menadžment, železnica, vučna vozila. 